\title{
Catequese e Civilização dos Índios nos Sertões do Império Português no Século XVIII
}

\author{
Núbia Braga RIBEIRO`
}

\begin{abstract}
Resumo: Este artigo analisa a catequese e civilização dos índios nas áreas de sertões da América portuguesa a partir das instruções e correspondências das autoridades. A troca de informações entre Estado português, religiosos e o governo na colônia desencadeou a elaboração de um conjunto de planos e propostas para o domínio dos povos indígenas e das terras repletas de riquezas, nos sertões do século XVIII. Os pressupostos da catequese e civilização integravam o projeto político-religioso do Estado como condição para a conquista na formação e manutenção do Império português e não como uma consequência. Assim, para o pensamento europeu, que vigorava, os habitantes da terra deveriam ser evangelizados dando sentido ao povoamento e colonização destas áreas.
\end{abstract}

Palavras-chave: Catequese; Civilização; Índios; Colônia.

\section{O Domínio dos Sertões e dos Índios}

A questão indígena na colônia foi projetada nas esferas religiosa e política, conforme a acepção de poder e domínio da época. As autoridades coloniais regeram a questão sem deixarem de lado o ideário evangelizador, mesmo que aparecesse no discurso político pautado em artifícios da conquista. Para compreender o propósito da catequese e

- Doutora pelo Programa de Pós-Graduação em História Social - FFLCH - Universidade de São Paulo - USP - 05508-900 - São Paulo - SP Brasil. A tese de doutorado Os povos indígenas e os sertões das minas do ouro no século XVIII, foi um estudo orientado pelo Professor Dr. Fernando Novais. E-mail: n8bia@yahoo.com.br

HISTÓRIA, São Paulo, 28 (1): 2009 
civilização do gentio deve-se compreender a mentalidade política:

as questões doutrinárias não podiam ser exclusivamente políticas; eram, antes de mais nada, problemas de consciência. $\mathrm{O}$ homo politicus em estado de pureza não existia. Nada podia ser algidamente objetivo: as idéias políticas e crenças mesclavam-se. O laicismo político é coisa dos nossos dias. A separação entre política e consciência, invenção de agora. (FRANÇA, 1997: 264).

Partindo da observação citada, o gentio tornou-se matéria de Estado, bem como a catequese e a civilização não estiveram apartadas da política e muito menos da religião. No caso dos sertões da América portuguesa, como centro vital do Império lusitano no século XVIII, tornou-se imprescindível pensar as estratégias de conquista, pois eram áreas onde as riquezas se encontravam abundantemente e onde os seus habitantes, os indígenas, estavam arredios ao contato com os desbravadores. Desta forma, os planos de catequese e civilização não devem ser pensados como algo externo ao Estado português e à religião, mesmo quando a jurisdição civil passou, também, à administração dos índios. Os sertões mais cobiçados no século XVIII correspondiam aos territórios entre Minas Gerais, Minas do Cuiabá e as Minas de Goiás. Os colonizadores e as autoridades designavam todos os grupos indígenas, do interior da colônia, com o termo "tapuia", sem considerar as inúmeras características diferentes entre eles. Embora soubessem da existência de grupos diversos em termos linguísticos, físicos e de seus ritos, eram de qualquer forma incluídos na condição de inferiores e violentos.

O controle sobre a terra e sobre o índio foi expresso antes mesmo do setecentos, apresentavam-se no Regimento de 1548 de Tomé de Sousa, nomeado para governador-geral, as instruções político-administrativas, mas o que chama atenção é quanto à justificativa declarada para a condição da conquista e da colonização: "a principal cousa que me moveo a mandar povoar as ditas terras do Brasil foi para que a jente dela se 
comvertese a nosa santa fee católica [...]." (THOMAS,1982: 220221). Assim, anunciava, oficialmente, as primeiras iniciativas da política indigenista, estabelecidas pelo Estado português, de caráter jurídico e político, mas o argumento se fundava na doutrina cristã (TAPAJÓS,1983: 204).

O rei tentou impor-se, representado pelas instituições que criou e pelas autoridades enviadas à colônia; não economizou nos procedimentos manifestos nas suas instruções. Como detentor dos meios legítimos, exerceu o poder político e "o Governo se tornou um imperativo para a sobrevivência da ordem social" (FRANÇA, 1997: 266). Entretanto, a vigilância e opressão foram mais intensas nas áreas de concentração da riqueza, pois a ordem política e social na colônia tinha como finalidade a ordem econômica. Segundo Fernando NOVAIS (1986), a metrópole transportou a riqueza num único rumo, o mercado europeu que se serviu das minas do ouro, como peça-chave da acumulação primitiva de capital, nos tempos modernos. No entanto, o êxito da empresa dependia de assenhorear os gentios. A Câmara de Vila Boa de Goiás, em carta de 28 de dezembro de 1788, ao solicitar à Coroa a permanência do governador Tristão da Cunha Menezes na administração, assinalava o fato de ele ter conseguido concretizar o descimento dos índios

e a redução principalmente do gentio da Nação Xavante, que acabava pôr em tranqüilidade a capitania devastada e reduzida ao ultimo estado por aquêles inimigos. Que jamais se tinha visto desentranharem-se de um sertão incluso e virem cheios de humildade e brandura misturarem-se com aquêles povos sem a desordem que se podia temer de tão grande multidão, chegando pelo que dizem perto de três mil. (DOCUMENTOS Históricos, 1928: 103-104).

O requerimento é translúcido quanto ao empenho da administração em domar o inimigo e os meios usados que aplacavam os problemas de se viver na colônia. Era explícita a política com relação aos índios nos moldes da catequese e a preocupação em civilizar o sertão que viria com a fundação de 
núcleos urbanos, levando, assim, o poder aos territórios ermos. Um exemplo disso ocorreu em 1739, quando Dom Luiz de Assis Mascarenhas, no tempo em que São Paulo administrava Goiás, partiu em execução à carta régia de 11 de fevereiro de 1736, para erigir uma vila. A vila criada, em 25/7/1739, foi denominada Vila Boa de Goiás, em homenagem a Bartolomeu Bueno e aos antigos habitantes Goiases. O nome da vila insinua a união dos dois oponentes, índios e colonizador, sob a vida em civilidade, demonstrando que a fundação de vilas era parte do planejamento urbano colonial.

Em carta do dia 25 de setembro de 1769, o governador das Minas Gerais instruía o sertanista Inácio Correia Pamplona quanto aos procedimentos na conquista da picada de Goiás, no sertão oeste. A campanha de Pamplona é uma jornada que revela o jogo de poder da conquista e as matrizes do pensamento dos modos de governar o Império. Além do caráter militar, da expedição, os rituais religiosos compunham a missão de doutrinar o sertão (NOTÍCIA diária e individual, 1988). Doutrinar o sertão significava a sagração do espaço hostil, a pacificação e civilização dos habitantes, o domínio do espaço com a abertura de caminhos, a construção de capelas e pontes, o cultivo de roças e a exploração de ribeiros auríferos (cf. BOXER, 1969).

A cada empreitada da conquista seguia-se a divulgação da fé e a cada capela erigida ou vila fundada realizava-se uma procissão e missa. Os núcleos de povoamento e a presença da doutrina cristã como elementos da conquista desenharam na paisagem rústica do sertão, parcialmente, a vitória do plano de catequese e civilização. A defesa da terra, a criação de fortalezas, o estudo e uso dos ribeiros foram assuntos pertinentes ao domínio do Império português, com o objetivo de obter um maior conhecimento dos recursos da terra, como analisa Ângela DOMINGUES (2001).

A apropriação do espaço vinha também acompanhada de símbolos do poder em certos pontos dos sertões e fronteiras, como as fortificações e os presídios; nas vilas, as câmaras, cadeias e o pelourinho. A urbanização e seu conjunto de 
construções imprimiam a presença do colonizador; era a prova material e simbólica da posse das terras, também concretizada nas concessões de sesmarias ao longo dos caminhos percorridos.

Uma das facetas do poder era representar a expressão do caráter civilizatório, pois a legitimidade política se estendia concomitante à ocupação territorial e as expedições concretizavam os ideais políticos e econômicos da conquista. As atividades agropecuárias nos sertões e a busca por metais preciosos acenaram para as oportunidades de riquezas em áreas de fronteiras, principalmente a partir da década de 1750. Embora as campanhas para os sertões tenham se iniciado nos anos 30 , foram revigoradas de forma estratégica nas áreas de passagem das rotas mercantis e escoamento dos produtos a partir da segunda metade do século XVIII. A intenção tornava-se realidade com o ordenamento das sociedades de sertões e a submissão às normas políticas, atributo para manter a governabilidade, um problema que preocupava o poder real no empreendimento do expansionismo do território e na arrecadação dos tributos. Assim, a demarcação dos limites entre fronteiras acertou o contorno do território, dilatando o espaço onde se estendia o poder e os tributos. Somente com a efetiva ocupação do solo e a fixação dos limites do Brasil se atingiria o domínio da terra e dos povos. De acordo com Sergio Buarque de HOLANDA (1977), a proteção das fronteiras foi alcançada com o expansionismo e por causa da ameaça constante das invasões estrangeiras, impondo, como indispensáveis os limites com a América espanhola.

No vasto território, nasceu uma série de contendas oriundas da convivência. Envolveram os índios e não só se restringiram às intrigas entre o poder temporal e o poder secular; envolviam também as autoridades civis e as competências de jurisdições. Apelava-se constantemente à Coroa para que interviesse nos agravos: "Se os vaçallos não tivessem o recurço de seos soberanos, que violencias não experementarião dos Ministros poderozos, e mal intencionados e 
principalm.te nas Conquistas aonde as largas distancias os fazem absolutos". (ANTT. Cod 6 fl.146, 20/07/1731).

Desta maneira, o século XVIII foi marcado por questões polêmicas quanto ao governo dos povos e da terra. Os comissários das duas cortes ibéricas de demarcação dos limites ao sul perceberam oposições internas à colônia, as quais foram notificadas pelo general Gomes Freire de Andrade, em 24 de março de 1753, quando afirmou serem os padres os sublevados, atropelando o andamento dos trabalhos de demarcação (BNL 477. F.322. Número IV. 4; 5).

De acordo com Jaime CORTESÃO (1958), o expansionismo alargou as fronteiras, mas a demarcação dos limites, por meio dos Tratados, era motivo de muitos debates. No centro-sul, comandava as operações Gomes Freire, enquanto do outro lado, comandava Francisco Xavier de Mendonça Furtado que, por diversos despachos e no cumprimento das ordens em 30 de abril de 1753, providenciou as conferências de demarcação dos limites da fronteira do rio Negro. $\mathrm{Na}$ empreitada, descobriu-se que os religiosos estavam envolvidos

com outro crime atrós de Leza Magestade não só se tinhão arrogado a authoridade de fazerem Tractados com as Naçoens Barbaras daquelles Sertoens dos Dominios da Coroa de Portugal, sem intervenção do Capitão General, e Ministros de Sua Magestade Fidelissima; mas tambem, que deste abominavel absurdo passárão ao outro ainda mais abominavel, de estipularem por Condiçoens dos mesmos Tractados o dominio supremo, e serviço dos mesmos. (BNL. 477. F.322. Número IV. 20).

Os padres desrespeitavam a Bula Pontifícia de 20 de dezembro de 1741 que havia declarado livres todos os índios no Brasil, numa disputa com os colonos pelo controle dos indígenas e poder do território (BNL. 477. F.322. Número IV. 21). A preocupação com a execução de um bom governo era mencionada nas Instruções régias para Francisco Xavier de Mendonça Furtado. Nelas, culpavam-se as desordens dos padres 
e dos índios pela ruína do Estado e orientava o governo que "o interesse publico, e as conveniências do Estado, que hides governar, estão indispensavelmente unidas aos negocios pertencentes a Conquista, e liberdade dos Índios". (BNL. Cód. 112595 F. 4829. fls.1-2).

Muito mais que se preocupar com a situação de exploração e abusos com os índios, estava em jogo o poder e a soberania do rei de Portugal, tornando os índios uma parte do cenário amplo da conquista. Na carta secreta a Gomes Freire, estavam as orientações e procedimentos para se efetivar as demarcações do sul e do norte. A Espanha cometia muitas fraudes nas demarcações, o que foi exposto na carta para Gomes Freire em 21 de setembro de 1751 e nas cartas de Sebastião José de Carvalho e Mello para seu irmão Francisco Xavier de Mendonça Furtado do Grão Pará, em 17 de Março de 1755 (PNA. Ref. COR 2021. Cota 54-XI-27 (16)). Se por um lado o espanhol era um inimigo externo, por outro, o gentio era um inimigo interno. Para se atingir o domínio dos povos e da terra, as duas frentes ameaçadoras de inimigos deveriam ser aniquiladas de maneira estratégica. Ao se traçar uma política de ação do norte ao sul da colônia, contava-se, para a plena execução, com Gomes Freire de Andrade e Francisco Xavier de Mendonça Furtado. Entre ambos circulavam as informações dos acontecimentos e as instruções dos modos de governar. Pombal enviou ao governador e capitãogeneral do Pará e Maranhão, em 17 de março de 1755, “[...] as ultimas q. haviao chegado de Gomes Freire de Andrada concernentes ao estado das Demarcações dos limites pela banda do Norte do Brazil até o mez de Outubro de 1754". Informava que para a negociação do "Tratado de Limites das Conquistas" não se via esforço por parte do Ministério de Madrid, por isso, desconfiados da Coroa espanhola, expediu a Gomes Freire de Andrada

a instrucção que se havia ajustado entre as duas Cortes que se dêo aos Respectivos Commissarios para a execução do Referido Tratado me mandou S. Mag.e instruir particularm.te o d.o General pela Secretissima Carta que lhe escrevi em 21 de 
Setembro de 1751, dando-lhe huma Cabal Noção dos motivos q. tinhao concorrido para ser bem fundada, e prudentíssima a desconfiança que havia do dito Ministério. (PNA. Ref. COR 2021. Cota 54-XI-27 (16) fl.16).

A cautela fazia-se necessária para impedir que os limites dos domínios portugueses se desfigurassem. Nas contendas do sul, no Rio Grande de São Pedro, as tropas enviadas para fazer as demarcações foram repelidas

pela rebeldia e inflluencia dos Tapues. E virem estes dar dous assaltos a huma Fortaleza que Gomes Freire havia feito levantar no Rio Pardo para lhe segurar o passo do Referido Rio, trazendo aquelles Barbaros peças d'artilheria de bater que certamente não forjarão nos Certões, que habitão; e declarando que obravão por ordem dos seus benditos Padres. (PNA. Ref. COR 2021. Cota 54-XI-27 (16) fl.17).

Os índios, também, tornavam-se um entrave para as demarcações dos limites que se traduziram cada vez mais em questão militar. Aconselhava-se Francisco Xavier de Mendonça Furtado: "Não deis passo que não seja seguro, nem aventureis couza alguma, quando o sucesso for dependente da boa fé, e da palavra dos Commissarios com quem conferires [...]." (PNA. Ref. COR 2021. Cota 54-XI-27 (16) fl.18). Dentre os objetivos das estratégias políticas, um era de criar um novo governo, o de "São Jozé do Rio Negro, pela indispensavel necessidade de se povoar essa fronteira occidental, e de segurarmos com ella a navegação do Rio da Madeira para o Matto-Grosso, e a passagem daquellas Minas para o Cuiabá". (PNA. Ref. COR 2021. Cota 54-XI-27 (16) fl.19). Reafirmava o Marquês de Pombal, nas Instruções, que como tem se sucedido na parte do sul com Gomes Freire de Andrada, devia-se seguir na parte norte, consumando o controle também dos sertões.

Defender a fronteira povoá-la, abrir caminhos, assegurar a navegação dos rios foram estratagemas para a viabilização do trajeto para as minas de Mato Grosso, às de Cuiabá e das Minas Gerais. A decisão se estendeu a todos os rios navegáveis de 
CATEQUESE E CIVILIZAÇÃO DOS ÍNDIOS NOS SERTÕES...

importância na ligação entre os sertões das riquezas que deveriam ser controlados, possibilitando a comunicação, a viagem e o domínio do território.

\section{O Perigo Índio nos Sertões do Ouro}

Uma relação muito antiga existe entre o poder instituído e a legislação. Como meio de repreensão aos "distúrbios sociais", transformam-se os desobedientes à ordem em elementos perigosos. Afinal, "existem muitas evidências sobre a brutalização e desmoralização que freqüentemente acompanham o estilo de vida de grupos que vivem fora de algumas normas sociais" (THOMPSON, 1987: 249). A idéia aplica-se aos índios rebeldes que foram igualados a "inimigos públicos", quando reagiam às investidas dos colonizadores, resultou no âmbito das relações sociais e culturais a legitimação do extermínio ou do domínio. Numa análise da legislação sobre os povos indígenas, Manuela Carneiro da CUNHA (1992) comenta que, apesar de complexa, ela exprime, em seu conjunto, a necessidade de controle sobre esses povos, como também, PERRONE-MOISÉS (1992: 115-132) demonstra o quanto as leis sobre os índios oscilaram como reflexos da busca incessante de submetê-los.

Dom Luís de Mascarenhas autorizou fazer guerra aos Paiaguá do Mato Grosso estendendo a decisão até Goiás. Em 6 de janeiro de 1742, estabeleceu um Regimento para regular a ação dos Capitães de Cavalos da Conquista dos Kaiapó, e os índios que se rendessem seriam levados para Vila Boa, onde o destino seria decidido por uma Junta com o governador. Entretanto, os que não se rendessem poderiam "passar a espada". Antonio Pires de Souza foi um dos que se utilizou da permissão, legitimada com o Regimento de 15 de julho de 1748, quando obteve poderes suficientes para investir contra os Kaiapó, estabelecendo aliança com os rivais Bororos. A partir dos combates de Antonio Pires, foram fundados os aldeamentos 
Sant'Ana, Rio das Pedras e Lanhoso, locais atualmente pertencentes ao Triângulo Mineiro (ATAÍDES, 1998: 24-25).

O obstáculo representado pelos povos indígenas existia em todas as regiões de sertões da colônia. O episódio da rendição dos índios Xavantes, no princípio de janeiro de 1788, era comemorado como um êxito, quando 3 mil índios foram reduzidos e aldeados no sítio do Carretão, a 20 léguas de Vila Boa de Goiás. Para a concretude do aldeamento, havia despesas, mas que obtinham a recomendação da Coroa na "conquista e civilização daqueles gentios." O sucesso da redução dependia de "poder-se atrair toda a nação destes gentios, com que ficará toda a capitania livre do embaraço que êles lhe faziam e possuindo as suas terras que êles deixam, e que podem ser tão úteis." (DOCUMENTOS Históricos, 1928: 99). Sem modéstia, declarava-se a redução como meio eficaz de controle dos gentios para pôr fim ao obstáculo que apresentavam na conquista do território.

A organização do ideal civilizador do gentio dos sertões seguiu até certo ponto os moldes propostos pelo Diretório dos Índios do Pará e Maranhão (1757-1798):

que rege as mais aldeias de todo o Estado do Brasil no parágrafo 78 dispõe que estas mesmas aldeias se forneçam de índios por meio dos documentos, ainda que seja à custa das maiores despesas da Real Fazenda; por efeito desta católica legislação, parece se deve aprovar ao governador as despesas que tem feito ao mesmo fim, ainda que para elas extraísse dos cofres dos reais quintos a sua importância, visto que as consignações ordinárias não podiam socorrer esta tão extraordinária e excessiva despesa (DOCUMENTOS Históricos, 1928: 99).

Apesar dos gastos com os aldeamentos, estes eram ainda menos dispendiosos que a guerra. A explicação tinha como base o subterfúgio da fé:

a conversão dêstes índios é o meio de dilatar a fé e fazer-se respeitado e conhecido neste novo mundo o adorável nome do nosso redentor, porém, ainda que êste é e foi sempre o principal 
CATEQUESE E CIVILIZAÇÃO DOS ÍNDIOS NOS SERTÕES...

objeto das católicas e religiosíssimas intenções de Vossa Majestade e dos augustíssimos predecessores, contudo desta espiritual e comum não só à real Coroa como igualmente aos moradores dos distritos de cada uma das capitanias do Brasil infestadas daqueles bárbaros, e por êste motivo lucram os povos daquele continente nos seus decimentos e obediência as suas terras a real Coroa e suposto que por êste título adquira a mesma o direito real delas outros vantajosos interesses concedia aos seus moradores. (DOCUMENTOS Históricos, 1928: 100).

O Diretório, definido como "católica legislação", reflete a tônica da conversão como condição da conquista, e não como sua consequência, isto é, no ideário era um dever do Estado expandir o cristianismo, zelar pela conduta espiritual dos habitantes da colônia, retirar o gentio da barbárie em que vivia, transformando-o, assim em utilidade para a própria conquista de que ele fazia parte. Quando não surtia efeito a redução dos índios e se instalava a resistência indígena ao propósito civilizador, mudava-se o jogo para o passo subsequente, no qual o índio era qualificado como inimigo. Conforme John MONTEIRO (1994), a guerra e o cativeiro foram premissas à solução de pôr fim aos ataques dos gentios bravios e às constantes formas de resistências desses povos.

Pombal, além de ordenar o estabelecimento do Diretório dos Índios e de tentar trazer o índio como aliado, investiu na fixação das fronteiras com tratados e comissões de demarcação. A construção de fortificações teve impulso nas regiões norte, sul e na fronteira a oeste da colônia. Do mesmo modo, Pombal enviou Instruções ao vice-rei do Brasil, Conde da Cunha, na carta de 26 de janeiro de 1765. Apontava as finalidades de sua política com o estabelecimento de povoações civis com índios, onde dizia que o convívio com os brancos os levaria à aprendizagem dos costumes nos núcleos urbanos, cessando os assaltos nos caminhos e vilas. Pretendia-se propiciar a integração à civilidade dos índios com objetivos bem transparentes de primeiro apaziguá-los e, em seguida, usá-los, também, na defesa do território (PNA. Códice 10624. FR. 1239). 
A relação entre Estado português, indígenas, colonos foi perpetrada por situações de violências, medos, guerras, alianças e estranhamentos, feixes que exprimem o modo como se deu o contato de culturas tão distantes e distintas (europeus e indígenas). Sob tensões ou não, aproximaram-se por meio de trocas e/ou desentendimentos, como um acontecimento peculiar e original na história da humanidade. A percepção dos índios era formada de acordo com a visão mítica que possuíam, no encontro com os europeus que, aliás, desaguou num desencontro, "o bem e o mal, a virtude e o pecado, o valor e a covardia tudo se confundia, transtrocando o belo com o feio, o ruim com o bom". (RIBEIRO 1995: 43). Dessa forma, para entender os desdobramentos oriundos desse contato, a cultura é uma instância que demarcou os limites entre uma e outra sociedade, como fruto das relações sociais específicas de um espaço-tempo.

Sérgio Buarque de HOLANDA (1985) analisa as similitudes do novo mundo com o Paraíso, mas que se apresentava com uma natureza repleta de signos inéditos para o europeu, porém traduzidos em seus significados. O espaço descoberto acenava que os sonhos impossíveis eram passíveis de serem realizados e tanto a própria terra quanto seus habitantes deveriam ser domados. Assim, fazia parte do pensamento lusitano converter os gentios considerados rudes, com aparência diferente e estranha do português. Nesse caminho, Laura de Mello e Souza (1989) analisa a edenização construída do Trópico pelo português e reflete sobre o estranhamento perante o outro, ou seja, o índio e seus costumes se encontravam na condição de animalidade, o modo como viviam era visto como absurdo e bestial pelo colonizador cristão. A exótica aberração dos costumes indígenas foi transferida para dar alicerce à conversão e somente teria um sentido se as populações ameríndias configurassem no campo religioso da catequese, cuja condição se justificava a conquista.

Adauto NOVAES (1996) ao abordar o momento da "descoberta" esclarece que as implicações para ambas as sociedades não se deram sem rupturas. A expansão, 
representada pela espada e a cruz, ganhava o simbolismo cristão - o de consagrar a expansão, episódio que transcendeu seu tempo e se tornou uma obra construída no processo histórico de Portugal. A partir das rupturas, elaborou-se a percepção das diferenças de mundos culturais tão distintos:

o reflexo no espelho da cultura não produz apenas o duplo, produz também a consciência da diferença. $\mathrm{E}$ foi exatamente porque as sociedades indígenas mostraram para o europeu o outro lado da história - faces de uma mesma realidade humana que hoje se pode dizer (o que nem sempre é reconhecido politicamente) que existem sociedades diferentes, formas diferentes de organização política, pensamentos diferentes que produzem diferenças no interior da própria idéia de ocidente. (NOVAES, 1998: 8).

A convivência índio-conquistador foi envolta pela incompreensão das visões de mundo das populações ameríndias e delas do mundo europeu. O tempo dos indígenas é marcado a partir dos rituais e dos espaços vividos - a terra -, conforme um movimento próprio que guia a vida e a sobrevivência - o nomadismo. O processo crescente dos aldeamentos impôs um fim à relação que mantinham com a natureza e encerrou, nas reservas, a vida dos gentios, comprimidos dentro de limites espaciais onde foram forçados a ficar confinados.

\section{Dominium, medo, castigo e fé}

Apesar das transformações e do contexto do século XVIII guardar uma gama de especificidade, é possível perceber a influência das discussões iniciadas com os missionários da Companhia de Jesus sobre a questão indígena, a escravidão e/ou a liberdade restrita, a tutela e a formação dos aldeamentos na América portuguesa. Entre os missionários, destacam-se as idéias de Manoel da Nóbrega que tiveram repercussão nos planos de catequese e civilização ao longo do período colonial, 
pois ele lançou algumas das diretrizes que se desdobraram numa política indigenista. Essas diretrizes nasceram com o Plano Civilizador na Carta de Nóbrega ao Padre Miguel de Torres em 1558 e do Diálogo sobre a Conversão do Gentio 15561557. Afinal, no caso do Brasil, as definições de domínio, sujeição, castigo, tutela e o assenhoramento dos índios foram estratégias elaboradas por NÓBREGA (1988). Ao longo de sua experiência em contato com as populações indígenas, tais palavras ganharam dimensões dentro de um campo de debates e de significados, os quais serviram ao conjunto de leis na política do Estado.

A forma de redução do gentio obedeceu às diversas tentativas, intercalada por mudanças, porém mesmo a partir da segunda metade do século XVIII, as premissas adotadas no início foram mantidas: o aldeamento, a tutela, a identificação do gentio entre aliado (pacífico) e inimigo (bravio), a guerra justa, a educação da religião e para o trabalho.

As necessidades decorrentes de educar os índios nos bons costumes e na fé cristã traduziram-se em leis que dirigiram a vida desses povos. Embora o Diretório dos Índios (1757-1798) com Pombal trouxesse inovações, a prática costumeira já estava impregnada da relação construída, ao longo do tempo, dos colonos com os gentios. As premissas gerais defendidas por NÓBREGA (1549-1560/1988) foram metamorfoseadas e tornaram-se a base que norteou as leis depois dele. Mudou-se a maneira de administrar os povos indígenas, como se percebe em ANTONIL (1711/1966), que acordou com os paulistas ceder à administração das aldeias dos índios em troca de renunciarem à entrada no sertão, o que nunca ocorreu de fato.

Os argumentos dos jesuítas justificaram de forma histórica, jurídica e teológica, os meios em que era permitida a escravidão do gentio no Brasil nos séculos XVI-XVII. A análise cautelosa dos textos missionários possibilita identificar a aceitação da escravidão indígena, em certos casos, na colônia. A montagem de uma política imposta aos índios é um componente dentro de um processo mais amplo. À medida que os contatos com a realidade colonial se expandiam, concomitantemente, as leis 
recebiam novos contornos. Foi a convivência que subsidiou a formulação das normas que regeram os relacionamentos entre indígenas e colonos. Os princípios jurídicos e teológicos, aos poucos, caracterizaram a política indigenista, o que, no início da colonização não estava de todo definido (cf. ZERON, 1998).

A concepção de persuasão, por exemplo, significava o uso do medo do castigo para converter os índios como método para mantê-los na doutrina. Juridicamente, decidiu-se pela escravidão aos pecadores, ou seja, os indígenas inimigos e pagãos, como maneira de aplicar-lhes uma punição. A Carta de 1558 marca no pensamento de Nóbrega a defesa da sujeição moderada, da conversão, da civilização pela persuasão e da gestão temporal dos aldeamentos, com leis próprias adequadas à educação dos índios. A criação de um espaço específico, com o aldeamento, permitiria impor o controle cotidiano da vida e dos costumes dos gentios. Com isso, a conversão andava lado a lado com a catequese e a civilização, mantida sob tutela.

O dominium foi se tornando consenso, tendo como instrumento a ameaça da punição ou o seu emprego. O medo, o castigo e a sujeição tornaram-se elementos que estiveram na base da política indigenista. Pretendia-se ao retirar os costumes dos índios em torná-los suscetíveis para conversão e sujeição. Um dos costumes que causava espanto e horror ao conquistador era o fato do gentio praticar a antropofagia, isto é, matava e comia grande número de cristãos, por isso foram qualificados como cruéis, bestiais e "carniceiros de corpos humanos." (NÓBREGA apud EISENBERG, 2000: 239).

Apesar dos interesses conflitantes entre colonos e Igreja, era questão comum a necessidade de controle do gentio pela pregação da religião cristã, a dissolução de seus costumes, a mudança de suas crenças e de seu cotidiano. A política indigenista marcada pelo dominium consolidou a tutela sobre os povos indígenas, como meio de apaziguar e conter as resistências desses povos diante da presença dos padres e dos colonos em suas terras. Junto ao avanço da cristandade no novo mundo, a transfiguração étnica, "processo através do qual os povos, enquanto entidades culturais, nascem, se transformam e 
morrem" (RIBEIRO, 1979:257), foi responsável pela dissolução das comunidades indígenas num longo embate de assimilação e segregação desses povos.

A catequese não só feria a visão de mundo dos índios, mas desejava arrancar-lhe do modo como viviam. Sabe-se que o elo entre identidade e alteridade se encontra na cultura de um povo; a alteridade requer a noção de diferente, o que só é possível de identificar quando se possui identidade. No caso dos índios e não índios, a relação não incluía o diferente, não era compreensível e nem desejável o outro, isto é, o índio para o colonizador. Conforme TODOROV (1988), a dificuldade de comunicação entre ambos pode ser explicada com base nas dimensões culturais diferentes, produzindo noções de tempo e de história que se projetaram no âmbito da conquista. Essas noções abrangem a alteridade e perpassaram as relações; afinal, é da alteridade que se define o que é ou não o diferente. A percepção do outro vem do parâmetro de comparação cultural. Os conquistadores, imbuídos do desejo de possuir a terra, não se contentaram em conviver nela com os índios; precisavam modificá-los ou extingui-los. Do fascínio derivado de exercer o poder sobre o outro e de ter de demonstrá-lo ao extremo, provocaram-se atos de crueldade e de extermínio.

Além do castigo ou do extermínio, o divisor de águas foi a conversão pela fé, na política indigenista, com a invenção do aldeamento que alterou o espaço vivido pelos povos indígenas, deslocando-os de lugar, assentando-os, com a intenção de mantê-los no contato com a fé e com a vida civilizada. A idéia de tutela vem da concepção de incapazes e de instáveis. Daí o aldeamento se tornar o espaço propício para aprenderem a disciplina, convivendo com regras e horários. Assim, a conversão ficaria garantida pela tutela, permitindo a correção do gentio e o aldeamento serviria à incorporação dele à sociedade colonial, sob a égide dos administradores. Dentre as consequências esperadas ao evangelizá-los, preservando-lhes a liberdade restrita, estava a obtenção de apoio militar para ir contra os índios inimigos e a exploração econômica da terra, usando-os como mão-de-obra. Conforme este ideal, os índios podiam servir 
de exército de mão-de-obra e exército militar na defesa do território contra os outros índios e contra os estrangeiros, pois os aculturados interessavam mais que os bravios, por poderem ser usados nos reais serviços.

As determinações constantes no Diretório dos Índios (1757-1798) reuniram muito do que se expõe. O domínio se consolidou na perspectiva de tutela mesmo com o Diretório. Ao final do século XVII e no XVIII, com a economia do ouro, ampliaram-se o uso do trabalho indígena nos diferentes tipos de propriedades desde as datas minerais às sesmarias, mas mantendo no discurso os pretextos de civilidade sob proteção, educação e assistência. O índio, como objeto de domínio, considerado de natureza incompleta e incapaz, deveria ser tutelado. O domínio fundamentou o direito de apropriação do gentio, deixando de lado a disputa em torno da escravidão para transformá-lo em trabalhador livre sob tutela (RIBEIRO, 2008). Apesar das mudanças ocorridas nessa política, seus princípios permaneceram e com isso os costumes desses povos foram modificados, incutiram-lhes uma fé, uma lei e um rei distantes, mas próximos e presentes por intermédio dos cristãos.

Os planos de catequese e civilização esclarecem muito mais da abrangência do pensamento em aniquilar a resistência dos índios do que a preocupação "humanitária" de convertê-los à fé e ao ideário civilizador. Ao discutir os planos, desvendam-se as intenções de dar um jeito a tanta gente espalhada causadora de problemas. Os argumentos propostos convergem para interesses comuns. Geralmente, iniciam-se com o ideal da catequese e terminam concluindo com os benefícios que se podem atingir com a civilização do gentio: terras, riquezas e mão-de-obra. Um exemplo foi o plano de catequese proposto pelo Padre Manoel de Jesus Maria, "natural da freguesia de Santo Antônio da Caza Branca, do Bispado de Mariana," em 1767. O Padre fez uma petição para ser vigário da Matriz da freguesia nova do Mártir São Manoel dos sertões dos rios do Peixe e Pomba, onde apresentava como justificativa do seu intuito cristianizar e civilizar os Cropós e os Croatos. Com esses índios bravos dos matos e sertões "[...] se acha vivendo entre 
aquelles bárbaros, pello zello da fé, e Serviço de V. Mag.de Cathequizando-os, baptizando-os, e Civilizando-os." (JESUS MARIA, 1897: 354). Em 1768, o Padre obteve o reconhecimento do poder civil, representado nas figuras do ouvidor e do governador Luis Diogo Lobo da Silva, que ordenou ao "capitão Jozé Gonçalves Vieyra dar índios que ele civilizou para acompanharem o Padre na diligência de aldear os índios bravos numa nova povoação" (JESUS MARIA, 1897: 357). Cabia ao Padre Manoel zelar pela conversão, "administrando-lhes os sacramentos, e absolvendo-os de todos os pecados, exceto os reservados atuais, voluntários, concumbinatos, e ocasiões próximas." (JESUS MARIA, 1897: 355-356).

Acreditava-se que os ensinamentos católicos forneceriam os subsídios à mudança dos hábitos bárbaros dos gentios para conduzi-los aos hábitos civilizatórios. Além disso, as áreas do rio Pomba foram marcadas por confrontos sangrentos entre índios Coroados, Cropós e exploradores. Na primeira metade do século XVIII, o capitão-mor Luís Borges Pinto explorou a região, fixou-se em Guarapiranga, de onde organizou combates violentos e apresou os índios. Em 1750, foi a vez do capitão Inácio de Andrade, que continuou os combates. Entretanto, como mencionado anteriormente, as propostas de sujeição dos índios finalizavam demonstrando os benefícios materiais com a conversão deles, pois os sertões eram objeto de interesse que, para se povoar, dependia da civilização e catequese do gentio, assegurando a extração das riquezas. O Governador, em 1768, ao mencionar a ordem do Secretário de Estado Francisco Xavier de Mendonça Furtado de 12 de fevereiro de 1765 e a Carta Régia de 14 de setembro de 1758, não o fazia por lembrança simplesmente, mas qualquer solicitação pertinente aos planos dos índios deveria convergir para o objetivo principal:

se atraião, Civilizem, e Cristianizem os Índios dos seus Domínios deste continente, mas se estabeleção deles lugares, e povoações, para os quais lhe manda dar Vigários, e Diretores de qualidades [...] e distintamente estende pelo referido aviso aos Índios desta 
Capitania, interessando-me igualmente na Conversão, Civilidade, e estabelecimento deles (JESUS MARIA, 1897: 359-360).

O Diretório, para as Minas, contém 53 pontos e refere-se ao sertão como espaço habitado pelos índios e lugar da barbárie, apesar da riqueza atraente escondida nas terras e rios. A identidade do espaço se definia de acordo com os costumes de seus habitantes, dos gentios nômades ou seminômades. $O$ sertão da barbárie e do paganismo chocou diretamente com a concepção de civilidade européia. O Diretório caracterizou, de forma genérica, o perfil dos índios ao assinalar que se conservavam "na mesma barbaridade como se vivessem nos sertões onde nasceram e praticando os costumes do paganismo. Só pela civilidade, cultura e comércio é possível civilizá-los." (DIRECTORIO, 1897: 700).

Estado e Igreja, por meio da cristianização dos gentios, pretendiam modificá-los e adaptá-los à utilidade como vassalos. Os diretores deveriam obedecer ao Diretório que destacava logo no primeiro ponto a importância de cristianizá-los sob os cuidados do Prelado da Diocese. A obrigação dos diretores seria persuadi-los para a civilidade e obrigá-los a aprender a língua dominante, "meio eficaz" para "desterrar" os "rústicos costumes da barbaridade." (cf. DIRECTORIO, 1897).

A preocupação em povoar a terra era descrita pela presença numerosa do bárbaro e ausência de braços para colonizá-la, "carecendo de muitos mil para povoallas, e cultivallas, colher os fructos, e defendel-os dos perigos que as apetecem e procurão conquistar". (BNL COD. 11259 F. 4829. fl. 34). A catequese foi formulada com base na opinião de que era impraticável a guerra contra a vastidão dos gentios que habitavam o Brasil. Também, entendia-se como um princípio cristão converter o "infinito gentio barbaro, que não tem fé, lei, nem Rei, nem forma de Republica, e vivem sem jugo, atropelam as leis da natureza, não fazem diferença de mães, e filhas para satisfazerem a sua lascívia." (BNL COD. 11259 F.4829. fl.2). Dessa maneira, a domesticação do gentio contemplava aspectos de ordem espiritual e temporal: 
No Espiritual fazendo a Deos o melhor serviço na conversão de milhões de almas daquelle gentilismo [...]. e no Temporal vindo para a communicação dos brancos nas suas cazas, lavouras e fabricas, onde como trabalhadores ganhando seus salarios, e não como escravos, se augmenta o commercio, e com elle as rendas de V. Magestade. (BNL COD. 11259 F. 4829. fl.2-3).

O Diretório dos Índios (1757-1798) regulamentou as funções dos administradores, determinando a execução da catequese e civilização, por isso a estreita relação de um com o outro. (ALMEIDA, 1997).

O Diretório dos Índios do Pará e Maranhão permite analisar o pensamento de um projeto de política indigenista mais amplo no Brasil e avaliar até que ponto foi empregado nas áreas de sertões. As especificidades das áreas mineradoras e de pedras preciosas devem ser entendidas num plano global, mas resguardadas certas distinções. Mesmo assim, as funções da conversão eram as mesmas para todas as partes da colônia, embora a realidade levasse a confrontos inevitáveis com os índios dos sertões. Apesar de não ter contado expressivamente com a presença dos jesuítas nos sertões, no século XVIII, a Igreja e outras ordens religiosas assumiram a catequese. Outra diferenciação pertinente quanto aos sertões é que os gentios ficaram mais entregues às expedições, aos sesmeiros e a milícias numa ação militarizada. O modelo de colonização era o de conquista da terra e foi entregue aos particulares a tarefa de povoamento, evitando maiores gastos dos cofres da Coroa. Entretanto, cabe dizer que a hostilidade dos índios não parou por causa da política indigenista e da legislação e muito menos por parte dos colonos de fazer-lhes guerra.

O conjunto de instruções e cartas entre autoridades permite apreender o que de fato incomodava-os, mesmo que sejam versões oficiais. As notícias dos lugares distantes da colônia analisam a realidade com o objetivo de tomar as decisões mais adequadas aos interesses das autoridades. Nelas, as autoridades, se valiam de advertências aos colonos ou, ao contrário, autorizavam-lhes as entradas e aos sesmeiros a 
ocupação do território. A administração dos índios tinha uma única finalidade ao aldeá-los: institucionalizar o dominium. Conforme a situação, legislava-se regulando a relação com os indígenas. Era de posse das informações que as autoridades trocavam idéias e decisões, se informavam dos acontecimentos, das tentativas de catequese dos índios, dos avanços, dos fracassos e das reações dos índios. Apesar da catequese e das propostas de sujeição do gentio terem sido criadas com base na experiência, em parte eram idealizadas porque a partir da realidade projetavam um ideal a ser atingindo, o que na maioria das vezes não se tornou possível.

A catequese era um projeto global para os índios do Brasil. Mesmo que fosse adaptado às realidades locais, deveria interligar as intenções da conquista de norte a sul do território. A recorrência ao discurso cristão das autoridades civis a partir da segunda metade do século XVIII indica que se inspiraram na cautela e reverência ao pensamento dos religiosos na gerência da administração dos índios. Quer-se dizer com isso que não houve exclusão dos padres, até porque a orientação da administração dos índios era fundamentalmente cristã, mas os padres passaram a conviver com a disputa e pressão dos leigos no controle dos índios.

As ações políticas registradas concernentes aos índios possibilitam perceber a interferência cultural cristã européia apregoada por um ideal que se inscrevia em defesa do "bem da civilização". As estratégias lançadas sob a artimanha da catequese até a maneira como se organizaram os aldeamentos e o dominium, integraram-se aos propósitos de sujeição dos índios dos sertões para libertar a terra do obstáculo que eles representavam para a exploração das riquezas.

\section{Agradecimentos}

Ao Professor Fernando Novais pela motivação e leitura criteriosa do estudo. Aos professores Vera Ferlini, Pedro Puntoni, 
Leila Mezan Algranti, João Antonio de Paula, Ângela Domingues pelos precisos comentários críticos sobre o assunto.

\section{Referências Bibliográficas}

ALMEIDA, Rita Heloísa de. O diretório dos índios: um projeto de civilização no Brasil do século XVIII. Brasília: Unb, 1997.

ANTT - Arquivo Nacional da Torre do Tombo de Lisboa. Cód. 06. fl.146.f e v. Sobre não procedimento das leis e dos vassalos que não seguem como deviam. Região de Minas e Cuyabá. Reais quintos do gentio. São Paulo, 20 de julho de 1731.

ANTONIL, André João. Cultura e opulência do Brasil por suas drogas, e minas (1711). 2. ed. Introdução por A.P. Canabrava. São Paulo: Companhia Editora Nacional, 1966.

ATAÍDES, Jézus Marco de. Sob o signo da violência: colonizadores e kayapó do sul no Brasil central. Goiânia: UCG, 1998.

BNL - Biblioteca Nacional de Lisboa. PBA 643 F. 1632. PBA 643 F. 1632. N.7 fl. 373. Índios nos rios de Guarapiranga, Pomba, Peixe com a presença de Diretores nomeados em 1768.

BNL - Biblioteca Nacional de Lisboa. Códice 112595 F. 4829. fl 1-19. Instruções Régias. (Instrucção particular, que V.Magestade he servido mandar dar a Francisco Xavier de Mendonça Furtado, nomeado Governador e Capitão General do Estado do Maranhão e Pará).

BNL - Biblioteca Nacional de Lisboa. PBA 477. F. 322. Número IV Relação Abreviada da Republica, que Os Religiosos Jesuitas das Províncias de Portugal, e Hespanha, Estabelecerão nos Dominios Ultramarinos das duas Monarchias, E da Guerra, que nelles tem movido, e sustentado contra os Exercitos Hespanhoes, e Portuguezes. Formada pelos registos das Secretarias dos dous respectivos Principaes Comissarios, e Plenipotenciarios; e por outros Documentos authenticos.

BOXER, Charles. O império colonial português. Trad. Inês da Silva Duarte. Lisboa/São Paulo: Edições 70/Martins Fontes, 1969. CORTESÃO, Jaime. Raposo Tavares e a formação territorial do Brasil. Rio de Janeiro: Serviço de Documentação/ Ministério da Educação e Cultura, 1958. 
CUNHA, Manuela Carneiro da (Org.). Legislação indigenista no século XIX. São Paulo: Edusp, 1992.

DIRECTORIO que se deve observar nas Povoaçoens dos Indios da Capitania de Minas Geraes, emquanto Sua Alteza Real não mandar o contrario. Revista do Arquivo Público Mineiro, Ouro Preto: Imprensa Oficial, ano II, fasc. 4, p.700-715, out./dez. 1897.

DOCUMENTOS Históricos. Arquivo Nacional do Rio de Janeiro. v. XCV Rio de Janeiro, Biblioteca Nacional. 1928. p.98-105.

DOMINGUES, Ângela. Para um melhor conhecimento dos domínios coloniais: a constituição de redes de informação no Império português em finais do Setecentos. História, Ciências, Saúde - Manguinhos, v. III, (suplemento), 2001. p.823-838.

EISENBERG, José. As missões jesuíticas e o pensamento político moderno: encontros culturais, aventuras teóricas. Belo Horizonte: UFMG, 2000.

FRANÇA, Eduardo D'Oliveira. Portugal na época da restauração. São Paulo: HUCITEC, 1997.

HOLANDA, Sérgio Buarque de. Visão do paraíso. 4 ed. São Paulo: Ed. Nacional (Brasiliana), 1985.

HOLANDA, Sérgio Buarque de (direção). História geral da civilização brasileira: a época colonial. Administração, economia, sociedade. 4 ed. São Paulo/Rio de Janeiro: Difel/Difusão Editorial S.A., 1977. t.I, v.2, Livro Primeiro: Política e Administração de 1640 a 1769. p.1921.(Colaborador: Pedro Octávio Carneiro da Cunha).

JESUS MARIA, Manoel de Padre. Sobre os índios do Pomba. Revista do Arquivo Público Mineiro. Ouro Preto, Imprensa Oficial, ano II, fasc. 2, p.354-362, abr./jun. 1897.

MONTEIRO, John Manuel. Negros da terra: índios e bandeirantes nas origens de São Paulo. São Paulo: Companhia das Letras, 1994.

NÓBREGA, Manoel da. Cartas do Brasil 1549-1560. Belo Horizonte: Itatiaia/ São Paulo: EDUSP, 1988. (Cartas Jesuíticas I).

NOTÍCIA diária e individual das marchas e acontecimentos mais condignos da jornada que fez o Senhor Mestre de Campo, Regente, e Guarda-mor Inácio Correia Pamplona, desde que saiu de sua casa e fazenda do Capote às conquistas do Sertão, até se tornar a recolher à mesma sua dita fazenda do Capote. (1769). Anais da Biblioteca Nacional, 1988, p.47-113.

NOVAES, Adauto (Org.). Tempo e história. São Paulo: Companhia das Letras, 1996. 
NOVAES, Adauto (Org.). A descoberta do homem e do mundo. São Paulo: Companhia das Letras, 1998.

NOVAIS, Fernando A. Estrutura e dinâmica do antigo sistema colonial (séculos XVI-XVIII). São Paulo: Brasiliense, 1986.

PERRONE-MOISÉS, Beatriz. Índios livres e índios escravos: os princípios da legislação indigenista do período colonial (séculos XVI a XVIII). In: CUNHA, Manuela C. da (Org.) História dos índios no Brasil. São Paulo: Companhia das Letras, FAPESP/SMC, 1992. p.115-132.

PNA - Palácio Nacional da Ajuda. Biblioteca da Ajuda, Lisboa. Ref. COR 2021. Cota 54-XI-27 (16). Cartas de Sebastião José de Carvalho e Mello para seu irmão Francisco Xavier de Mendonça Furtado do Grão Pará. fl.16-20. Lisboa em 17 de Março de 1755.

PNA - Palácio Nacional da Ajuda. Biblioteca da Ajuda, Lisboa. Códice 10624. FR. 1239. Cartas do Marques de Lavradio. Cartas do Marques de Pombal. Informações do sul, rio Grande, rio Pardo, Pernambuco, outras partes da colônia e do Conde de Bobadella. Século XVIII.

RIBEIRO, Darcy. O Povo Brasileiro. A formação e o sentido do Brasil. 2 ed. Companhia das Letras, 1995.

RIBEIRO, Darcy. Os índios e a civilização. 3 ed. Petrópolis: Vozes, 1979. RIBEIRO, Núbia Braga. Os povos indígenas e os sertões das minas do ouro no século XVIII. Departamento de História, FFLCH, USP-SP, 2008. (Tese Doutorado).

SOUZA, Laura de Mello e. O diabo e a terra de Santa Cruz: feitiçaria e religiosidade popular no Brasil colonial. 2ed. São Paulo: Companhia das Letras, 1989.

TAPAJÓS, Vicente Costa Santos. A política administrativa de D. João III. 2 ed. Brasília: UNB,1983. "Regimento que levou Tomé de Sousa, primeiro governador-geral do Brasil 1548. p. 204-205.

THOMAS, Georg. Política indigenista dos portugueses no Brasil. 15001640. São Paulo: edições Loyola, 1982.

THOMPSON, Edward Palmer. Senhores e caçadores: a origem da lei negra. Trad. Denise Botmmann. Rio de Janeiro: Paz e Terra, 1987.

TODOROV, Tzvetan. A conquista da América: a questão do outro. Trad. Beatriz Perrone Moisés. 2 ed. São Paulo: Martins Fontes, 1988.

ZERON, Carlos. La Compagnie de Jésus et l'institution de l'esclavage au Brésil: les justifications d'ordre historique, théologique et juridique, et leur intégration par une mémoire historique (XVI-XVII siècles). Thése (Doctorat Histoire et Civilizations) - l'École des Hautes Estudes en Sciences Sociales de Paris le 16 juin 1998. 
RIBEIRO, Núbia Braga. Catechesis and Civilization of native Indians in the "Sertões" of the Portuguese Empire in the $18^{\text {th }}$ century. História, v.28, n.1, p.321-346, 2009.

\begin{abstract}
This article proposes a discussion of the factors that contributed to the settling within the Portuguese possessions along the shores of the Indian Ocean, namely the construction of fortresses along this coastline. These settlements represented an official strategy of establishment within the territory and of control of the commercial routes. Simultaneously, however, private individuals sought other forms of becoming wealthy which were very often contrary to the Portuguese crown's interests. The analysis of these two lines of action is based on the definition of strategies and tactics proposed by Michel de Certeau.
\end{abstract}

Keywords: The State of Portuguese India; Portuguese fortresses; Strategies and tactics.

Artigo recebido em 03/2009. Aprovado em 06/2009 